\title{
Rancang Bangun Cooler Box Termoelektrik Dengan Air Sterilizer Sebagai Tempat Pengiriman Air Susu Ibu (ASI)
}

\author{
Gostsa Khusnun Naufal ${ }^{1 *}$, Muhammad Amiruddin ${ }^{2}$ \\ ${ }^{1}$ Teknik Mesin, Fakultas Teknik dan Informatika, Universitas PGRI Semarang \\ Jl. Sidodadi Timur no 24 Semarang \\ ${ }^{2}$ Teknik Elektro Fakultas Teknik dan Informatika, Universitas PGRI Semarang \\ Jl. Sidodadi Timur no 24 Semarang \\ *E-mail: gostsakhusnunnaufal@gmail.com
}

Diterima: 04-12-2019; Direvisi: 20-12-2019; Dipublikasi: 31-12-2019

\begin{abstract}
Abstrak
Tren yang berkembang saat ini adalah asi ekslusif yang diberikan kepada bayi sampai dengan bayi tersebut mempunyai usia yang cukup. Hal ini tentunya tidak terlalu bermasalah pada ibu rumah tangga yang sebagian besar waktunya berada di rumah, sehingga dapat menyusi bayi tersebut tanpa gangguan. Tetapi hal ini berbeda dengan wanita karir yang memiliki bayi dan ingin memberikan asi eksklusif, jarak yang jauh antara rumah dan tempat kerja serta keterbatasan waktu menjadi faktor penghalang yang membuat asi eksklusif menjadi sangat sulit diberikan oleh wanita karir kepada anaknya. Cooler box dapat menjaga agar suhu asi tetap dalam kondisi dingin mencegah kerusakan kandungan asi. Didalam cooler box dimasukkan ice gel yang membuat suhu tetap dingin. Ice gel tersebut dapat menjaga suhu tetap dingin selama 3-4 jam. Permasalahan lain adalah kehigienisan dari cooler box serta wadah penyimpan dari asi. Tidak jarang cooler box menjadi sumber bakteri yang dapat menyebar ke asi yang terdapat pada cooler box, hal ini bisa diakibatkan kelembapan ataupun dari tangan yang tidak steril. Hal ini dikarenakan dalam proses pumping serta pemindahan ke dalam cooler box masih menggunakan cara manual dengan tangan. Peneliti akan merancang bangun cooler box dengan menggunakan termoelektrik sebagai pendingin dari cooler box serta memiliki air sterilizer, yang berguna menurunkan jumlah bakteri dengan menggunakan uv light. Kadar bakteri yang rendah akan membuat cooler box menjadi lebih higienis sebagai tempat penyimpanan asi ketika akan dikirimkan.
\end{abstract}

Kata kunci: air sterilizer, cooler box, termoelektrik, uv light.

\begin{abstract}
The growing trend today is the exclusive breast milk given to the baby until the baby has a sufficient age. This is certainly not too problematic for housewives who most of the time are at home, so it can menyusi baby without interference. But this is different from career women who have babies and want to provide exclusive breast milk, a great distance between home and workplace and time constraints become a barrier factor that makes exclusive breast milk becomes very difficult given career woman to her child. Cooler box can keep asi temperature remain in cold condition prevent damage of breast milk content. Inside the cooler box put ice gel to keep the temperature cool. The ice gel can keep the temperature cool for 3-4 hours. Another problem is the hygiene of the cooler box and storage container from the breast milk. Not infrequently the cooler box into a source of bacteria that can spread to the breast milk contained in the cooler box, this can be caused moisture or from the hands that are not sterile. This is because in the process of pumping and transfer into the cooler box is still using the manual by hand. The researcher will design a cooler box build by using thermoelectric as cooling from cooler box and have water sterilizer, which is useful to decrease the amount of bacteria by using uv light. Low levels of bacteria will make the cooler box becomes more hygienic as a storage area when it will be shipped.
\end{abstract}

Keywords: air sterilizer, cooler box, termoelektrik, uv light

\section{Pendahuluan}

Tren yang berkembang saat ini adalah pemberian asi ekslusif kepada bayi dengan harapan bayi tersebut memiliki perkembangan tubuh yang sempurna. Pemberian asi ekslusif pada bayi tentunya tidak terlalu bermasalah pada ibu rumah tangga yang sebagian besar waktunya berada di rumah. Tetapi hal ini berbeda dengan wanita pekerja yang memiliki bayi dan ingin memberikan asi eksklusif, jarak yang jauh antara rumah dan tempat kerja serta keterbatasan waktu menjadi faktor penghalang yang membuat asi eksklusif menjadi sangat sulit diberikan oleh wanita karir kepada anaknya. Salah satu solusi dari permasalahan tersebut adalah melakukan pumping asi. Pumping asi adalah kegiatan menampung asi yang 
keluar kedalam sebuah wadah (Gambar 1). Untuk kerusakan asi jika berada pada suhu ruangan adalah dengan menempatkan asi kedalam cooler box (Gambar 2).

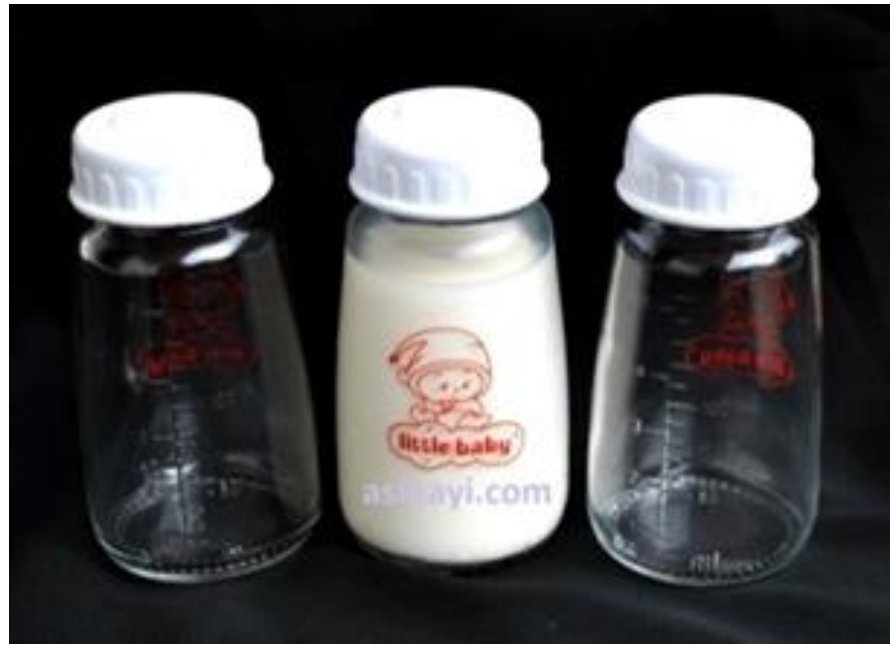

Gambar 1. Tempat asi (www.asibayi.com)[1].

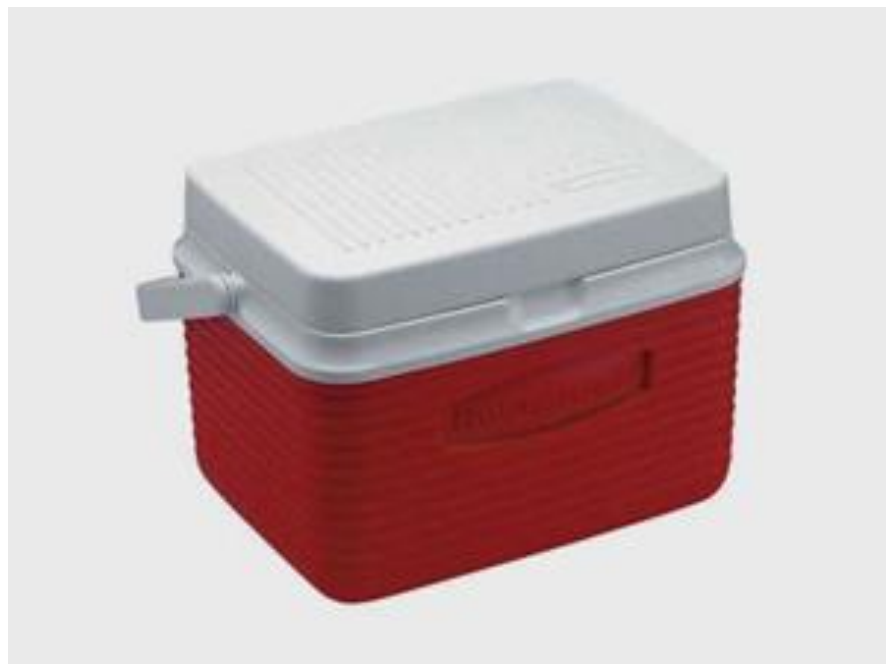

Gambar 2. Cooler box (www.asibayi.com)[1].

Cooler box dapat menjaga agar suhu asi tetap dalam kondisi dingin mencegah kerusakan kandungan asi. Didalam cooler box dimasukkan ice gel yang membuat suhu tetap dingin (Gambar 1.3). Ice gel tersebut dapat menjaga suhu tetap dingin selama 3-4 jam. Tetapi kekurangan dari ice gel adalah sebelum digunakan ice gel harus dimasukkan ke dalam lemari pendingin selama 7-8 jam.

Cooler box dapat menjaga agar suhu asi tetap dalam kondisi dingin mencegah kerusakan kandungan asi. Didalam cooler box dimasukkan ice gel yang membuat suhu tetap dingin (Gambar 1.3). Ice gel tersebut dapat menjaga suhu tetap dingin selama 3-4 jam. Tetapi kekurangan dari ice gel adalah sebelum digunakan ice gel harus dimasukkan ke dalam lemari pendingin selama 7-8 jam.

Permasalahan lain adalah kehigienisan dari cooler box serta wadah penyimpan dari asi. Tidak jarang cooler box menjadi sumber bakteri yang dapat menyebar ke asi yang terdapat pada cooler box, hal ini bisa diakibatkan kelembapan ataupun dari tangan yang tidak steril. Hal ini dikarenakan dalam proses pumping serta pemindahan ke dalam cooler box masih menggunakan cara manual dengan tangan. 


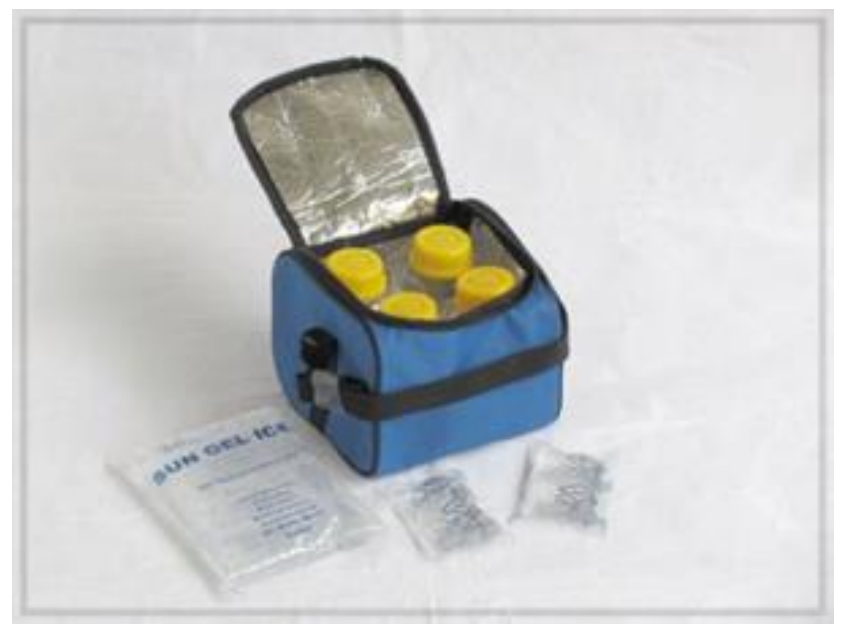

Gambar 3. Cooler box dengan ice gel (www.medicastore.com).

\section{Material dan metodologi}

\subsection{Elektrik Cooler Box}

Cooler box yang menggunakan tenaga listrik sebagai pendinginnya menggunakan modul termoelektrik sebagai media pendingin (Gambar 3). Modul tersebut akan menyerap kalor yang berada di dalam cooler box kemudian membuang kalor tersebut ke udara bebas. Catu daya yang digunakan pada cooler box jika digunakan di dalam mobil menggunakan cigarette lighter, dimana catu daya tersebut berdaya 12 volt. Tetapi jika digunakan di dalam rumah cukup dengan menghubungkan kabel catu daya listrik ke stop kontak dirumah. Ukuran dari cooler box bermacam-macam, mulai dari cooler box yang hanya dapat menampung beberapa kaleng alumunium soda sampai dengan yang memilliki kapasitas belasan liter. Kapasitas penampungan cooler box akan berbanding lurus dengan jumlah daya yang dikonsumsi ketika cooler box tersebut digunakan. Waktu penggunaan dari cooler box ini tidak terbatas waktu, karena menggunakan sumber daya listrik maka cooler box akan tetap dapat digunakan selama catu daya masih tersambungkan. Tidak seperti cooler box non elektrik yang tergantung pada ice gel yang semakin lama akan menurun, sehingga ice gel perlu dimasukkan ke dalam freezer kembali untuk menurunkan suhunya.

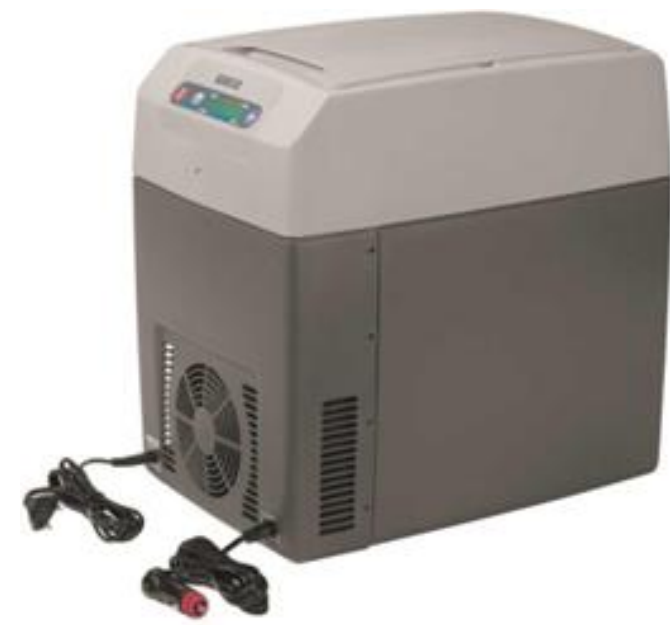

Gambar 4. Cooler box dengan tenaga listrik (www.enortec.com). 


\subsection{Termoelektrik}

Pendingin termoelektrik (Gambar 4) atau Thermo Electric Cooler (TEC) merupakan sebuah semikonduktor yang dapat memindahkan kalor dari sisi satu ke sisi lainnya dengan memanfaatkan efek peltier, TEC juga sering disebut dengan pendingin Peltier. TEC ini terbentuk dari semikonduktor tipe $\mathrm{N}$ serta semikonduktor tipe $\mathrm{P}$, yang disusun dalam plat tembaga. Plat tembaga tersebut menghubungkan semikonduktor P dengan semikonduktor N, kemudian pada tiap plat tembaga akan dilapisi dengan isolator seperti ditunjukkan pada gambar 5 Saat TEC / Peltier dilewati arus maka alat ini akan memindahkan panas dari satu sisi ke sisi lain, biasanya menghasilkan perbedaan panas sekitar $40^{\circ} \mathrm{C}-70^{\circ} \mathrm{C}$ antara sisi satu dengan sisi yang lainnya. Apabila salah satu sisi termoelektrik semakin panas maka akan semakin kurang efisiensinya. Karena termoelektrik perlu untuk mengurangi atau menghilangkan panas yang ditimbulkan dari proses pendinginan maupun dari panas yang dihasilkan oleh daya listrik yang diumpankan. Jumlah panas yang ditimbulkan sebanding dengan arus yang diberikan kepada modul serta berapa lama waktu modul tersebut digunakan. Pembuangan panas pada satu sisi termoelektrik dapat menggunakan sirip alumunium yang langsung dilekatkan pada sisi panas peltier dan dapat ditambahkan kipas pada sirip alumunium sebagai upaya untuk mempercepat membuang panas pada sirip alumunium.[5]

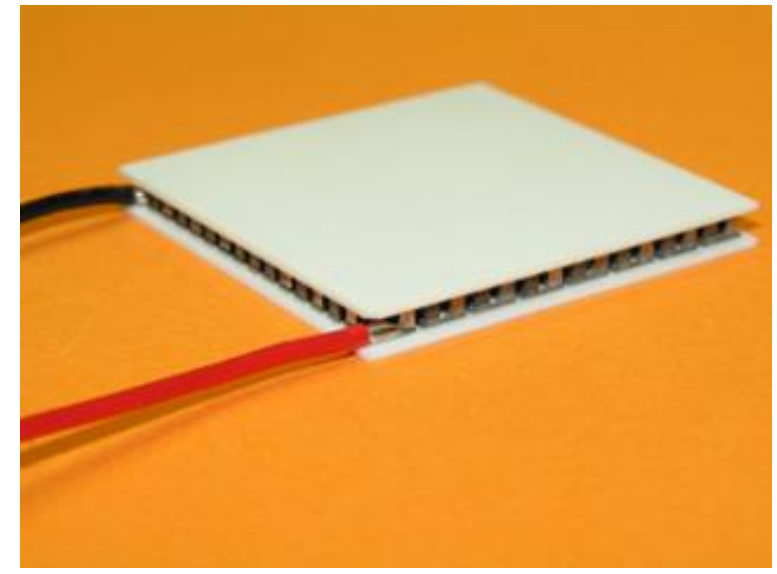

Gambar 5. Modul termoelktrik (www.thermoelectric.com).

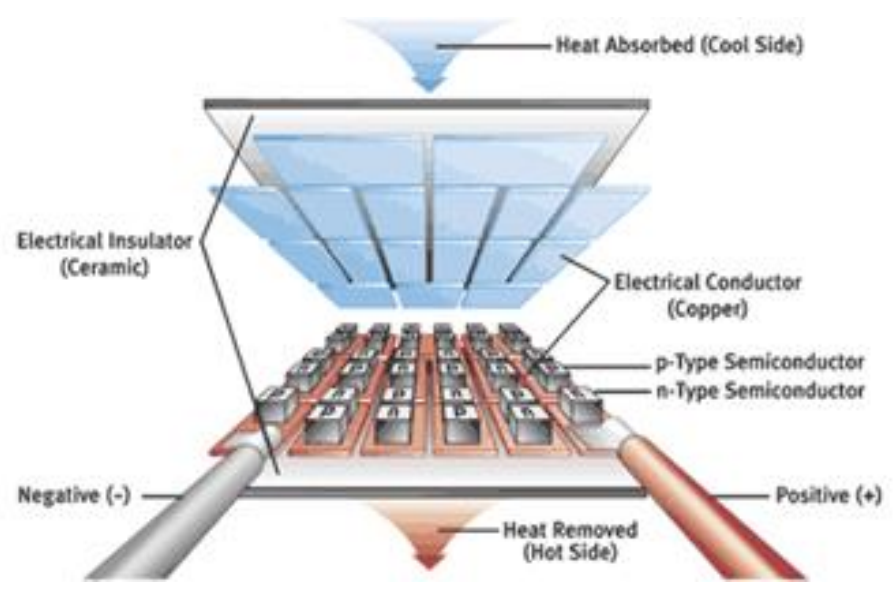

Gambar 6. Susunan dari peltier modul (peltiermodules.com) 


\subsection{Air sterilizer}

Udara merupakan salah satu media penyebar bakteri. Hal ini dapat membuat suatu ruangan menjadi terkontaminasi oleh bakteri hanya karena aliran udara, salah satu cara mencegah kontaminasi bakteri melaui udara adalah dengan menggunakan metode germicidial air. Germicidal air atau pensterilan udara dengan menggunakan uv light banyak digunakan dalam dunia medis, salah satunya pada sistem sirkulasi udara pada ruang pasien (Gambar 6). Dimana udara yang ada diruang pasien akan dilewatkan pada alat khusus yang berisi lampu ultra violet dengan panjang gelombang tertentu. Udara yang melewati alat tersebut akan mendapatkan penyinaran ultraviolet, dimana bakteri yang ikut bersirkulasi dalam udara tersebut dapat dimatikan[6].

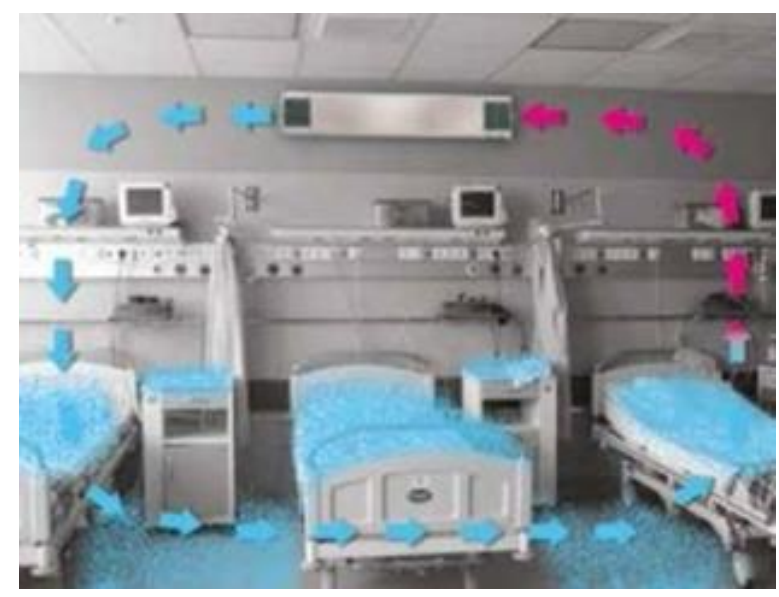

Gambar 7. Proses germicidal air pada ruang pasien (www.ultraviol.pl)

Jenis sinar ultar violet dengan panjang gelombang $254 \mathrm{~nm}$ atau sinar ultra violet jenis C. Dengan panjang gelombang tersebut dapat langsung membunuh bakteri yang terkena sinar uv. Seperti dijelaskan pada gambar 2.7 cahaya uv-c dapat menembus inti dari bakteri serta menghancurkannya, sehinga bakteri tersebut akan mati.

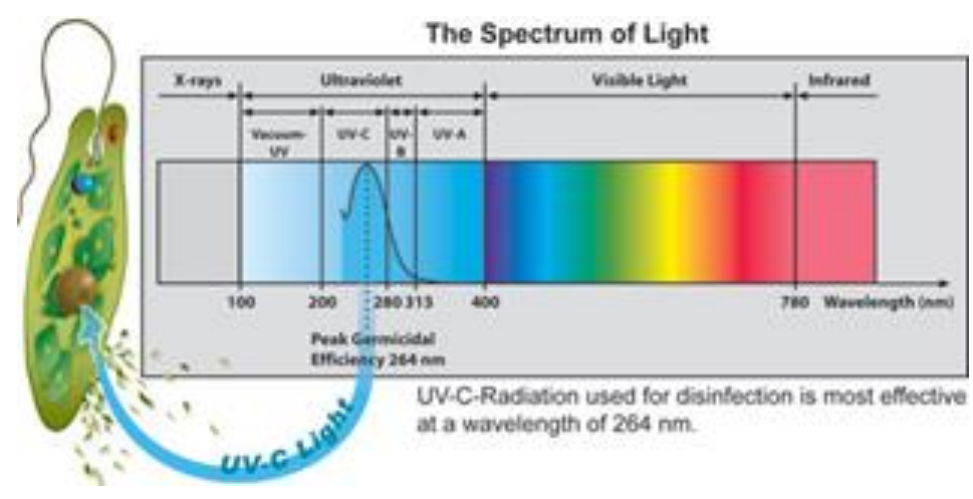

Gambar 8. Panjang gelombang dari cahaya (newimg.globalmarket.com).

Pembangkitan sinar uv-c dapat menggunakan uv light, tetapi uv light yang khusus menghasilkan sinar dengan panjang gelombang antara $260 \mathrm{~nm}$. Penggunaan dari uv light dengan jenis c ini memerlukan penanganan khusus karena berbahaya jika terkena manusia. Sehingga ditempatkan pada ruang khusus, sehingga cahaya dari lampu tersebut tidak memancar bebas, tetapi memancar pada ruangan tersebut saja. Intensitas atau kekuatan penyinaran dari tergantung dari watt lampu uv, semakin besar watt dari lampu uv tersebut semakin besar intensitas penyinarannya. Besar intensitas penyinaran juga berpengaruh pada luasan daerah yang dapat disinari oleh cahaya uv-c. 


\section{Hasil dan pembahasan}

Diagram alir penelitian dan langkah pengujian dari usulan penelitian ini dapat dilihat pada Gambar 9

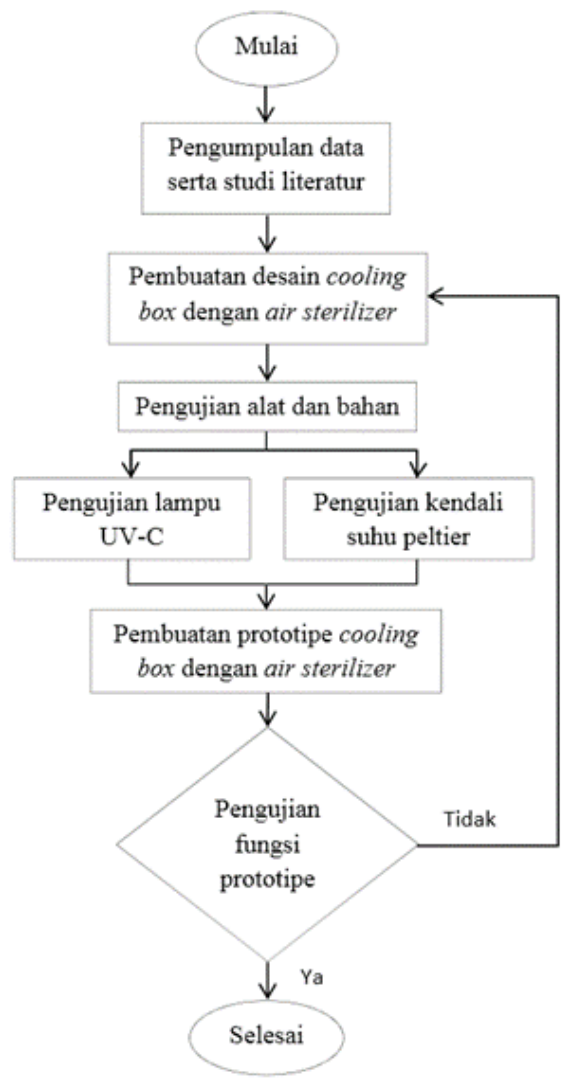

Gambar 9. Diagram alir penelitian.

Langkah pertama dalam melakukan penelitian tentang rancang bangun cooler box termoelektrik dengan air sterilizer sebagai tempat pengiriman air susu ibu (asi) adalah dengan pengumpulan data serta studi literatur mengenai teknologi pendinginan menggunakan termoelektrik serta sistem pengendali dari termoelektrik tersebut, diharapkan akan didapatkan sistem pendinginan yang efisien. Kemudian pengumpulan studi literatur mengenai germicidial air menggunakan lampu ultra violet yang menghasilkan cahaya dengan panjang gelombang uv-c. Diharapkan dengan data yang didapatkan cara penggunaan lampu uv-c dengan efektif dalam membunuh bakteri dalam udara [10].

Setelah studi literatur dilakukan, maka akan diteruskan dengan pembuatan desain prototipe cooler box dengan air sterilizer. Dari desain yang dibuat akan dipilih satu desain yang memenuhi kriteria sesuai dengan tujuan penelitian. Desain terpilih tersebut akan dilakukan uji alat serta bahan penunjang, sistem utama dari prototipe cooler box dengan air sterilizer adalah pendingin dengan termoelektrik serta pensteril udara menggunakan uv light. Sistem pendingin menggunakan termoelektrik diuji apakah sistem mampu menghasilkan suhu sesuai dengan yang diinginkan, serta dapat menjaga pada suhu tersebut pada kurun waktu tertentu. Pada sistem pensteril udara menggunakan uv light yang menghasilkan uv tipe c, adalah dengan menggunakan bakteri yang sudah diketahui jumlahnya kemudian akan dilakukan pensterilan udara pada suatu ruangan kecil. Setelah perlakuan tersebut dilakukan akan dilakukan penghitungan ulang pada jumlah bakteri tersebut apakah jumlah bakteri dapat berkurang ataukah bertambah.

Langkah selanjutnya dengan pembuatan prototipe cooler box dengan air sterilizer dari desain yang terpilih serta sistem yang telah diuji cobakan. dari pembuatan prototipe tersebut akan disimulasikan kembali fungsi-fungsi dasar dari. 
Meliputi fungsi menurunkan suhu asi dalam prototipe cooler box dengan air sterilizer serta menurunkan jumlah bakteri yang berada pada prototipe cooler box dengan air sterilizer. Jika dalam pengujian lanjutan tentang fungsi dasar dari prototipe cooling box dengan air sterilizer maka penelitian dianggap telah selesai serta dilanjutkan dengan publikasi seminar. Tetapi jika dalam pengujian tersebut prototipe cooler box dengan air sterilizer tidak dapat memenuhi persyaratan yang telah ditetapkan maka proses penelitian akan dikembalikan pada proses pembuatan desain cooler box dengan air sterilizer.

\subsection{Pembuatan Cooler Box Dengan Air Sterilizer}

Rancang bangun cooler box dengan air sterilizer dilakukan dengan mendesain komponen penyusun cooler box. Komponen yang didesain merupakan komponen utama dan komponen pendukung dari cooler box.

Hasil dari desain 3 dimensi kemudian akan dicetak menggunakan printer 3 dimensi. File dari Solid Work akan diterjemahkan kedalam G Code menggunakan bantuan software Repetier, dengan terlebih dahulu disimpan dengan ekstensi dotSTL. Desain komponen pertama yang dicetak adalah isolator peltier. Peltier yang digunakan pada penelitian ini berjumlah 4 buah. Dimana peltier tersebut harus diberikan sekat atau isolator antara sisi heat sink yang berfungsi membuang kalor atau panas dengan sisi dingin dari peltier. Sekat tersebut berfungis menghalangi perpindahan kalor dari sisi panas ke sisi dingin, sehingga sisi dingin dapat mencapai suhu yang optimal dalam waktu yang cepat. Komponen yang selanjutnya adalah holder dari kipas pendingin heat sink, heat sink merupakan media pembuangan kalor yang diserap oleh peltier ke udara bebas. Untuk mempercepat pembuangan kalor ke udara bebas dibuatlah sistem udara paksa dengan menggunakan bantuan kipas angin. Kipas angin yang digunakan berjumlah 2 buah yang berfungsi menghembuskan serta menyedot udara yang dilewatkan pada heat sink. Holder tersebut memegang kipas angin dan mengarahkan udara yang dihembuskan agar mengarah pada kisi - kisi heat sink [8].

Pemasangan peltier pada heat sink melalui beberapa tahapan. Langkah pertama dengan memasang isolator pada heat sink menggunakan lem. Isolator ditempatkan berdampingan memanjang searah panjang heat sink. Optimalisasi perpindahan kalor dari peltier ke heat sink ditambahkan thermal paste pada sisi heat sink maupun pada sisi dingin peltier. Peltier dipasang dengan sisi dingin menghadap berlawanan dengan plat pendingin, peltier dipasang didalam isolator yang telah dicetak (Gambar 10).

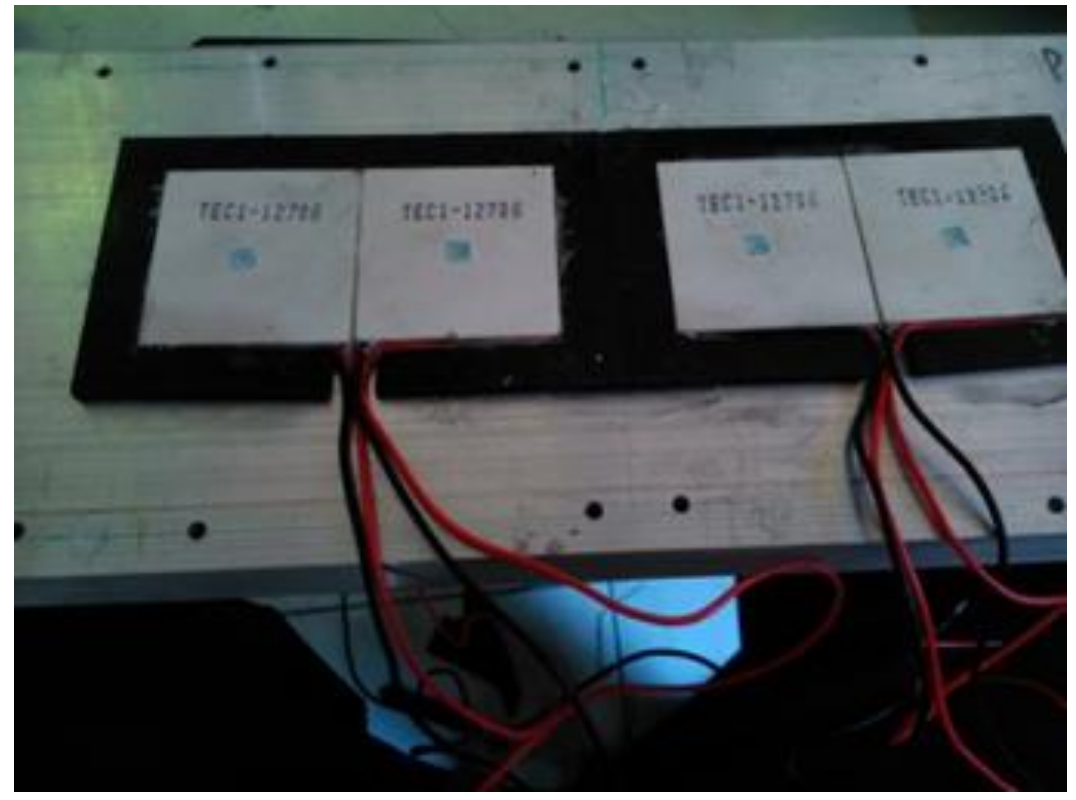

Gambar 10. Peltier pada heat sink. 
Plat pendingin (gambar 11) tersebut berfungsi menyerap kalor dari box strerofoam yang berakibat turunnya suhu pada bagian dalam sterofoam. Penggunaan sterofoam sebagai wadah yang dapat mengisolasi masuknya kalor dari luar sistem ke dalam sistem, dikarenakan sterofoam yang bersifat isolator.

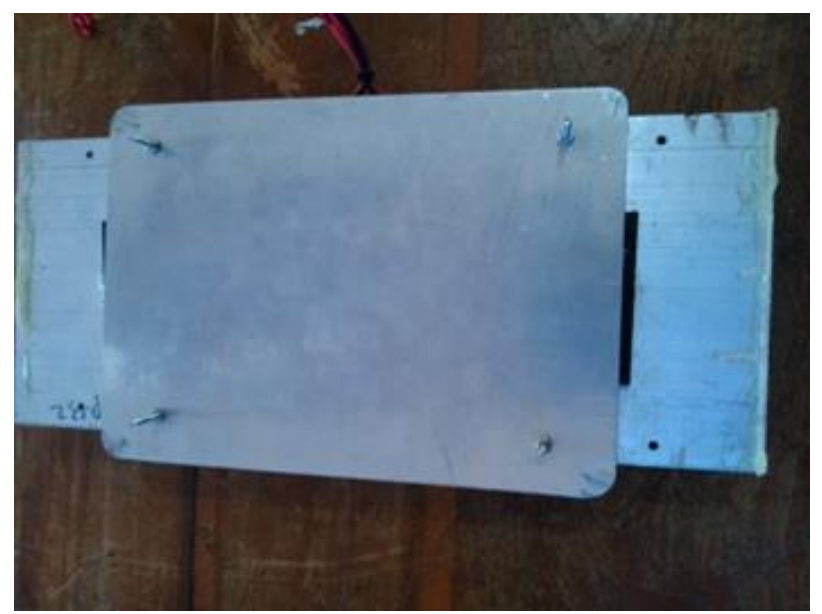

Gambar 11. Pemasangan plat pendingin.

Komponen utama dalam sistem germicidial air adalah lampu UV-C produksi PHILIPS (TUV 8W FAM) tampak pada Gambar 4.8. lampu uv ini menggunakan catu daya sebesar 56 volt dc dengan menggunakan kontroler. Data spesifikasi dari lampu uv ini dapat dilihat pada tabel 4.1. Sedangkan lampu uv ini akan menghasilkan sinar dengan panjang gelombang yang termasuk pada UV-

Lampu UV akan diberikan ruangan (Gambar 12) untuk media sirkulasi udara sebagai proses sterilisasi. Lampu UV ini tidak diperbolehkan terpapar langsung ke kulit manusia, dikarenakan akan merusak sel kulit. Kemudian seluruh komponen akan dirakit dan dipasangkan pada kotak strerofoam

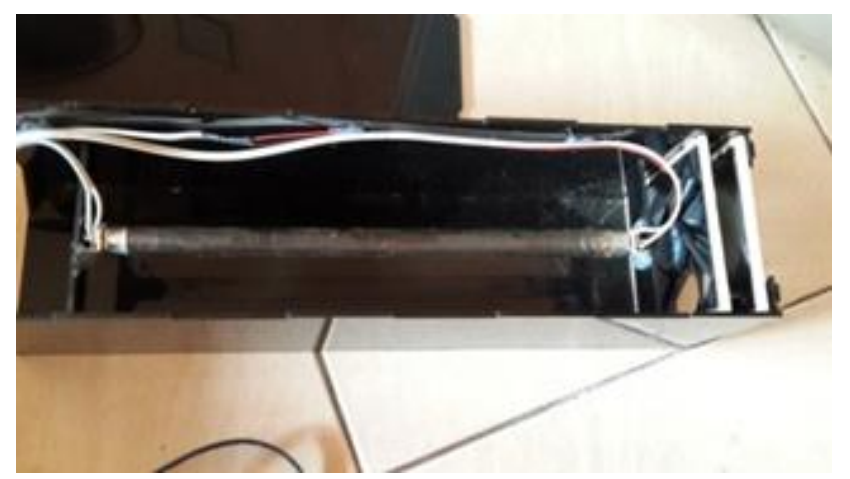

Gambar 12. Ruangan germicidial air.

\subsection{Pengujian Cooler Box Dengan Air Sterilizer}

Pengujian pertama dilakukan dengan pengujian suhu permukaan plat pendingin peltier. Peltier diberikan catu daya yang sesuai dengan spesifikasi, catu daya yang digunakan sebesar 12 volt 30 amper. Data yang diambil berupa suhu serta kecepatan pendinginan menggunakan sensor termocouple Data yang didapat dapat dilihat pada tabel 1. Pengujian germicidial air dapat dilihat pada Tabel 2 
Tabel 1. Pengujian Peltier

\begin{tabular}{|c|c|c|}
\hline No & Waktu (Detik) & Suhu (celcius) \\
\hline 1 & 0 & 29 \\
\hline 2 & 10 & 27 \\
\hline 3 & 20 & 25 \\
\hline 4 & 30 & 23 \\
\hline 5 & 40 & 22 \\
\hline 6 & 50 & 20 \\
\hline 7 & 60 & 20 \\
\hline 8 & 70 & 20 \\
\hline 9 & 80 & 20 \\
\hline 10 & 90 & 20 \\
\hline 11 & 100 & 20 \\
\hline
\end{tabular}

Tabel 2. Pengujian Germicidial Air

\begin{tabular}{cccc}
\hline no & $\begin{array}{c}\text { Waktu } \\
\text { treatment } \\
(\text { menit })\end{array}$ & $\begin{array}{c}\text { Kontaminasi } \\
\text { Bakteri } \\
\left(\mathbf{c f u} / \mathbf{m}^{2}\right)\end{array}$ & $\begin{array}{r}\text { Kontaminasi } \\
\text { fungi }\left(\mathbf{c f u} / \mathbf{m}^{2}\right)\end{array}$ \\
\hline 1 & 0 & 207 & 102 \\
2 & 15 & 48 & 31 \\
3 & 30 & 25 & 11 \\
4 & 45 & 15 & 6 \\
\hline
\end{tabular}

\section{Kesimpulan}

Dari Tabel 1 dapat diketahui mengenai penurunan suhu pada sisi plat pendingin. Pengambilan data dilakukan setiap 10 detik. Pada awal pengujian didapatkan data suhu plat pendingin sebesar $29^{\circ} \mathrm{C}$. Kemudian setelah berjalan 10 detik suhu plat pendingin menurun menjadi $27^{\circ} \mathrm{C}$. Penurunan suhu terjadi sampai detik ke 50 mencapai suhu $20^{\circ} \mathrm{C}$, pada detik 
60 sampai dengan detik 100 tidak terjadi penurunan suhu. Hal ini dimungkinkan pada sisi panas kipas yang berfungsi membuang udara panas yang diserap peltier sudah tidak mampu membuang kalor lebih banyak.

Pengujian alat germicidal udara dilakukan pada ruangan tertutup dengan suhu dan kelembaban tertentu. Ventilasi ruangan ditutup untuk mencegah udara luar masuk kedalam ruangan. Pengukuran kontaminasi mikroorganisme udara dilakukan sebanyak satu kali untuk masing-masing kondisi pada cawan uji. Pengukuran pertama dilakukan pada udara yang belum disterilisasi menggunakan alat germicidal. Kemudian pengukuran kedua dilakukan setelah udara disterilkan selama 15 menit. Pengukuran ketiga dilakukan setelah udara disterilisasi selam 30 menit dan pengukuran yang keempat dilakukan sterilisasi setelah 45 menit. Hasil pengujian germicidial air dapat dilihat pada tabel 2

Pada tabel 2 diperoleh data penurunan jumlah koloni bakteri maupun jumlah koloni jamur pada menit pertama dan pada menit 45 didapatkan jumlah bakteri menurun dari $207 \mathrm{cfu} / \mathrm{m}^{2}$ menjadi $15 \mathrm{cfu} / \mathrm{m}^{2}$. Kemudian pada jumlah fungi atau jamur dari $102 \mathrm{cfu} / \mathrm{m}^{2}$ menjadi $6 \mathrm{cfu} / \mathrm{m}^{2}$

\section{Daftar Pustaka}

[1] _ _. Cooler box dengan Ice gel, www.asibayi.com; 2016 [Diakses pada tanggal 1 Agustus 2019]

[2] _. Cooler box dengan tenaga listrik, www.enortec.com; 2016 [Diakses pada tanggal 4 Agustus 2019]

[3] _. Cooler box, www.asibayi.com. [Diakses pada tanggal 1 Agustus 2019]

[4] _., Ice gel, www.asibayi.com. [Diakses pada tanggal 1 Agustus 2019]

[5] _.., Modul termoelktrik, www.thermoelectric.com. [Diakses pada tanggal 1 Agustus 2019]

[6] _.., Panjang gelombang dari cahaya, newimg.globalmarket.com. [Diakses pada tanggal 1 Agustus 2019]

[7] _.., Proses germicidal air pada ruang pasien, www.ultraviol.pl. [Diakses pada tanggal 1 Agustus 2019]

[8] _ _.., Susunan dari peltier modul, peltiermodules.com. [Diakses pada tanggal 1 Agustus 2016]

[9] _.., Tempat asi, www.asibayi.com. [Diakses pada tanggal 1 Agustus 2019]

[10] M. H. Jali. Development of Smart Breast Milk Incubator. Scholars Journal of Engineering and Technology (SJET), Universiti Teknikal Malaysia Melaka. Malaysia.2015. 